
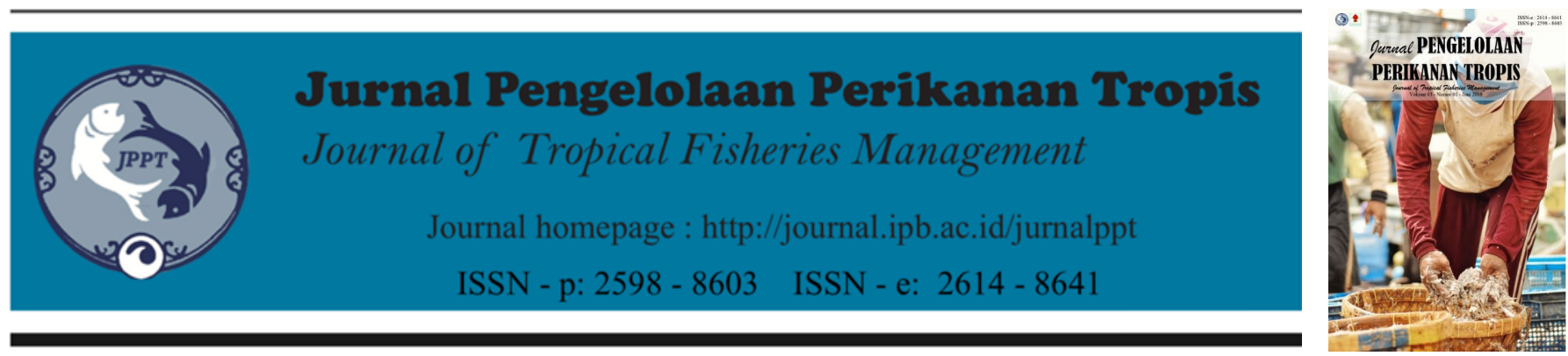

\title{
Gonad Maturity and Fecundity of Bluecheek Silver Grunt (Pomadasys argyreus) in Palabuhanratu Bay, West Java
}

\author{
Kematangan Gonad dan Fekunditas ikan gerot-gerot (Pomadasys argyreus) di Teluk Palabuhanratu, \\ Jawa Barat
}

\section{Mona Agatha*, Yonvitner, Rahmat Kurnia}

Department of Aquatic Resources Management, Faculty of Fisheries and Marine Science, Bogor Agricultural University, 16680 Bogor, Indonesia

\begin{tabular}{|c|c|}
\hline ARTIKEL INFO & ABSTRAK \\
\hline $\begin{array}{l}\text { Article History } \\
\text { Recevied: } 24 \text { Januari } 2019 \\
\text { Accepted: 05 April } 2019\end{array}$ & \multirow{2}{*}{$\begin{array}{l}\text { A total of } 806 \text { fish samples were collected from the catch of local fishermen. The sex } \\
\text { ratio of Pomadasys argyreus was 1:0,90. Four stages of gonadal development were } \\
\text { observed in males and females, which dominated by stage I and II (immature). The } \\
\text { highest gonadosomatic index (GSI) in males was } 1,14 \text { in September, while in females } \\
\text { was } 1,80 \text { in May. Length at first maturity of Pomadasys argyreus was } 140,12 \mathrm{~mm} \text { for } \\
\text { males and } 135,01 \mathrm{~mm} \text { for females. The highest value of condition factor was } 1,05 \text { for } \\
\text { males and } 1,10 \text { for females. This fish spawn partially (partial spawner) and estimated } \\
\text { spawns throughout the year with a spawning peak in June. }\end{array}$} \\
\hline $\begin{array}{l}\text { Keywords: } \\
\text { bluecheek silver grunt, reproduction, } \\
\text { Palabuhanratu Bay }\end{array}$ & \\
\hline
\end{tabular}

Corresponding Author

Mona Agatha, Department of Aquatic

Resources Management, Faculty of

Fisheries and Marine Science, IPB

University, 16680 Bogor, Indonesia.

Email: monaagatha@gmail.com

\section{INTRODUCTION}

Palabuhanratu Bay is a coastal area located on the southern coast of West Java, Indonesia. The biggest potential of Palabuhanratu Bay is fisheries. Bluecheeksilver grunt (Pomadasys argyreus) is one example of potential fish that captured in Palabuhanratu Bay, West Java, Indonesia. This fish has a silvery body color with some blue hint on its cheek, yellowish-brown fin and thick scales. These demersal fish live in shallow waters with low salinity and high temperatures (Safi 2014).

The English names of grunt due to their ability to make loud sound by rubbing their pharyngeal teeth (Tavera et al. 2012). These fish are spread to Indo-West Pacific, Pakistan to Sri Lanka and to the east to Southeast Asia. Pomadasys argyreus has dorsal fin with 12 strong spines and 13 soft rays, anal fin with three spines and 8 soft rays.

Genus Pomadasys consist of 34 species that widely distributed (Al-Faisal and Mutlak 2018). Six species was found in Indonesia. There were $P$. argyreus, $P$. kaakan, P. maculatus, $P$. hasta, $P$. argenteus, and $P$. furcatus.

Although many of $P$. argyreus was found in Indonesia, their reproductive data are still very limited. This study was conducted to provide information about reproductive aspects of $P$. argyreus in Palabuhanratu Bay, West Java as a basis for consideration of management policy of $P$. argyreus resources.

\section{MATERIALS AND METHODS}

\section{Fish sampling}

A total of 806 fish samples of $P$. argyreus were obtained from small-scale fisheries at the Fishery Port of Nusantara (PPN) Palabuhanratu, West Java, by using gill net. Fish samples were collected by using simple random sampling, during May to September 2017. Samples transported to the laboratory and preserved in a deep freezer until the analysis. Each sample was measured to the nearest $1 \mathrm{~mm}$ for total length and to the nearest $1 \mathrm{~g}$ for total weight. Fish sexes and gonad maturity was visually observed. The 
quantity off egg (fecundity) was analyzed by using gravimetric method. Egg diameter was observed by using binocular microscope with 10x10 magnification.

\section{Sex ratio}

Sex ratio was analyzed by comparing the number of male to female fish and assessed using Chi-square test.

\section{Gonad maturity}

Gonad was visually classified into four stages based on characteristics described by Falahatimarvast (2012).

\section{Gonad Somatic Index (GSI)}

The GSI values was calculated by the following formula:

$$
\text { GSI (\%) }=\frac{\text { Gonad weight }}{\text { Fish body weight }} \times 100
$$

\section{Length at first maturity}

The length at first maturity was estimated according to Spearman-Karber equation (Udupa 1986).

\section{The condition factor}

The condition factor for each sampling month was calculated by the following formula (Effendie 2002):

$$
\mathrm{CF}=\frac{\mathrm{W}}{\mathrm{aL}^{\mathrm{b}}}
$$

Where $\mathrm{W}$ is fish body weight $(\mathrm{g}), \mathrm{L}$ is fish total length $(\mathrm{mm}), a$ and $b$ are constants estimated by length-weight relationship.

\section{Fecundity estimation}

Fecundity was calculated by the following formula (Effendie 1979):

$$
\mathrm{F}=\frac{\mathrm{G}}{\mathrm{Q}} \times \mathrm{N}
$$

$\mathrm{F}$ is fecundity (eggs), $\mathrm{G}$ is gonad weight $(\mathrm{g}), \mathrm{Q}$ is weight of sample gonad ( $\mathrm{g}$ ) and $\mathrm{N}$ is number of eggs in the sample gonad (eggs).

\section{RESULTS}

Bluecheek silver grunt sexes were defined from visual observation. A total number of fish samples obtained in this study was 806 individuals consisting of 425 males and 381 females. Males ranged in length from 62 to $205 \mathrm{~mm}$ and females from 73 to $253 \mathrm{~mm}$. The sex ratio of males to females $(1: 0,9)$ was proportional and not significantly different from $1: 1$ sex ratio $\left(\chi^{2}=2,40\right.$ $\left.>\chi^{2}{ }_{h}=3,18\right)$ (Table 1).

In this study, four stages of gonadal development were observed in male and female $P$. argyreus (Table 2). These were stage I, stage II, stage III and stage IV. Stage I and stage II (immature) were dominant, while stage IV (mature) was found monthly (Figure 1). This result showed that $P$. argyreus in Palabuhanratu Bay has the potential to spawn during the observation time, which is from May to September. Spawning of $P$. argyreus commenced throughout the year. Males dominating at length ranged between 122 to $136 \mathrm{~mm}$, and between 123 to $147 \mathrm{~mm}$ for females, with variations of gonad stage compotition. Length growth no significant effect on gonad maturity, because gonadal stages did not increase as in corresponds to length. Highest frequency of stage IV gonads for males and females $P$. argyreus was found in June.

The highest GSI value of males $P$. argyreus were found in September (1.14) and the lowest were found in August (0.70). The highest GSI values for females were found in May (1.80) and the lowest were in June (0.96) (Figure 2). The average total GSI for males and females was 1.02 and 1.49 , respectively. The relationship between length and GSI was analyzed, the result showed that GSI had no significant effect on fish length. The $r$ value in respect to males and females were 0,12 and 0,13 .

The length of first maturity was analyzed to estimate the population growth. The estimated value, $\mathrm{Lm}=140,12 \mathrm{~mm}$ for males and $\mathrm{Lm}=$ 135,01 for females (Figure 3). The condition fac-

Table 1 The sex ratio of Pomadasys argyreus in Palabuhanratu Bay during the observation time

\begin{tabular}{lccccc}
\hline Observation time & $\begin{array}{c}\text { Total number } \\
(\mathrm{N})\end{array}$ & $\begin{array}{c}\text { Number of } \\
\text { males }\end{array}$ & $\begin{array}{c}\text { Number of } \\
\text { females }\end{array}$ & $\begin{array}{c}\text { Sex Ratio } \\
(\mathrm{M}: \mathrm{F})\end{array}$ & Information \\
\hline May 2017 & 153 & 71 & 82 & $1: 1,15$ & proportional \\
June 2017 & 163 & 81 & 82 & $1: 1,01$ & proportional \\
July 2017 & 73 & 43 & 30 & $1: 0,70$ & proportional \\
August 2017 & 154 & 93 & 61 & $1: 0,66$ & not proportional \\
September 2017 & 263 & 137 & 126 & $1: 0,92$ & proportional \\
\hline \multicolumn{1}{c}{ Total } & 806 & 425 & 381 & $1: 0,90$ & proportional \\
\hline
\end{tabular}


Table 2 Description of gonadal development stages (Falahatimarvast 2012)

\begin{tabular}{|l|l|l|}
\hline \multicolumn{1}{|c|}{ Stage } & \multicolumn{1}{|c|}{ Male } & \multicolumn{1}{c|}{ Female } \\
\hline I-Immature & $\begin{array}{l}\text { Testes are very small, thin and translu- } \\
\text { cent. }\end{array}$ & $\begin{array}{l}\text { Ovaries are very small and translucent. In } \\
\text { resting stage, slightly coloured. }\end{array}$ \\
\hline II-Developing & $\begin{array}{l}\text { Wider gonads occupying 1/4 of visceral } \\
\text { cavity. Testes turning to whitish. }\end{array}$ & $\begin{array}{l}\text { Ovaries are reddish or yellowish. Individu- } \\
\text { al oocytes are not visible to the naked eye. }\end{array}$ \\
\hline III-Ripening & $\begin{array}{l}\text { Gonads occupying 3/4 to all of the vis- } \\
\text { ceral cavity. Testes are white but there } \\
\text { is no running sperm. }\end{array}$ & $\begin{array}{l}\text { Ovaries are yellow and opaque oocytes re } \\
\text { visible to the naked eye. }\end{array}$ \\
\hline IV-Spawning & $\begin{array}{l}\text { Gonads are large, occupying the whole } \\
\text { visceral cavity. Testes are white, have a } \\
\text { milky hue and are running ripe. }\end{array}$ & $\begin{array}{l}\text { Ovaries are fully or partially translucent } \\
\text { and gelatinous. Hyaline oocytes are visi- } \\
\text { ble. }\end{array}$ \\
\hline V-Spent & $\begin{array}{l}\text { Gonads decrease in volume and become } \\
\text { flaccid. Testes are empty. }\end{array}$ & Ovaries are empty and turn reddish. \\
\hline
\end{tabular}

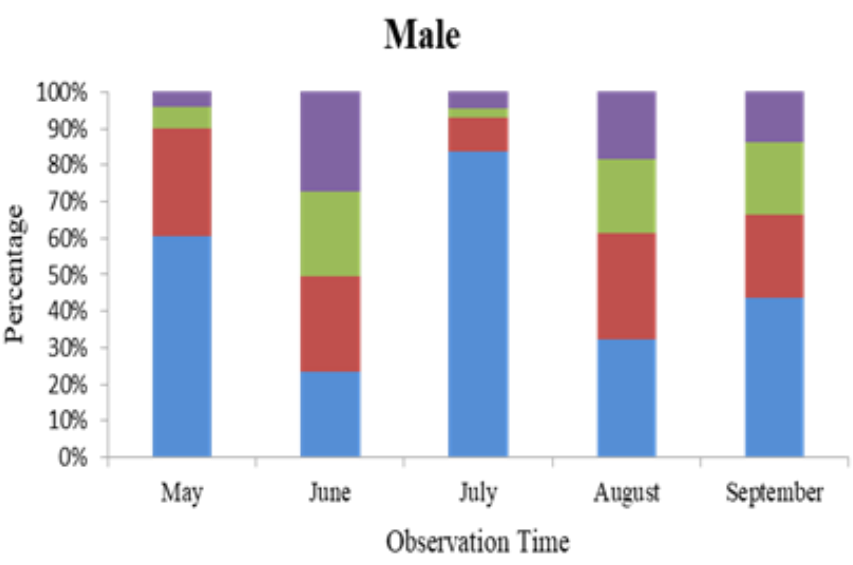

"Stage I $\|$ Stage II | Stage III $=$ Stage IV

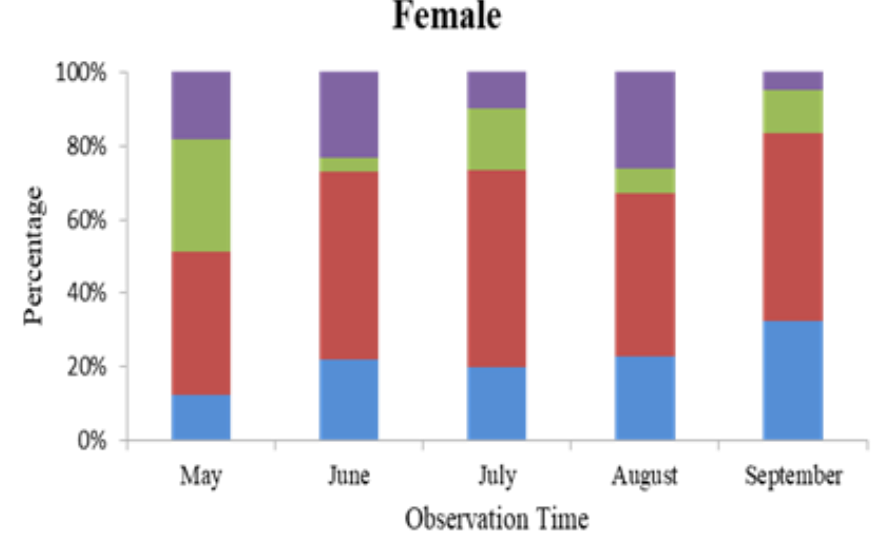

- Stage I $\mid$ Stage II | Stage III $=$ Stage IV

Figure 1 Frequency of gonadal development stages of Pomadasys argyreus
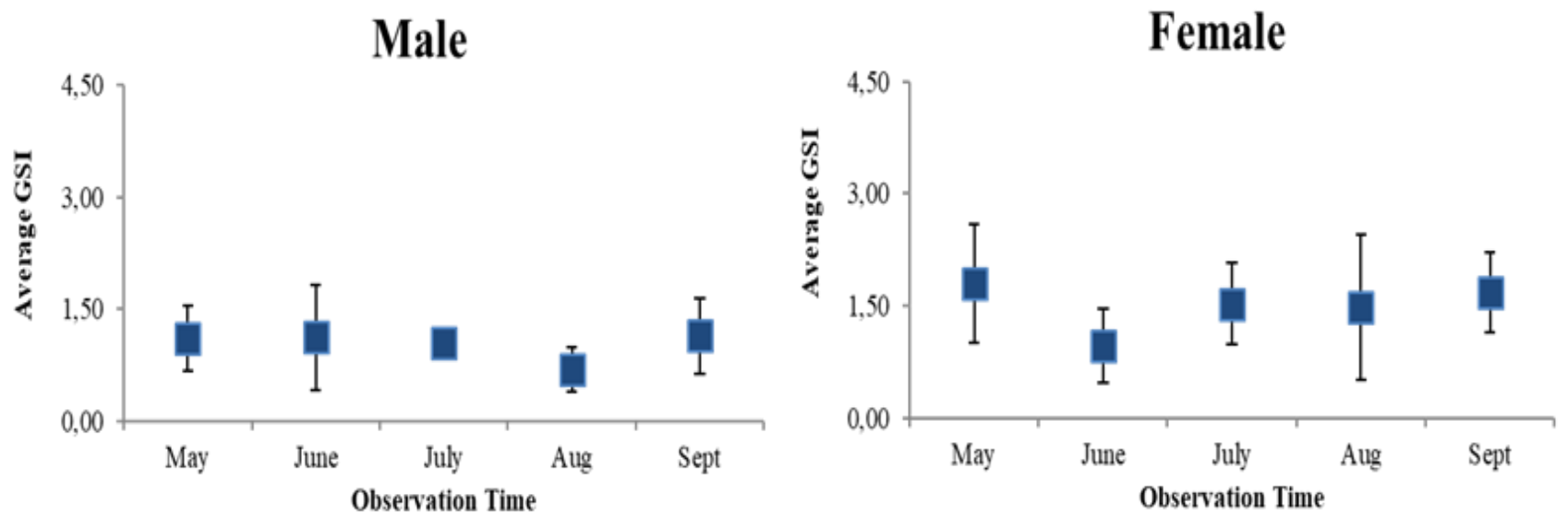

Figure 2 Monthly variations of the GSI for Pomadasys argyreus in Palabuhanratu Bay

1,10 for females. The highest value of condition factor on male $(1,05)$ and female $(1,10)$ were found in July.

The fecundity of $P$. argyreus in this study was 10.405 to 43.182 eggs for each month. The highest fecundity was found in July. The diameter of eggs was dominated by size 0,355 to $0,405 \mathrm{~mm}$, which showed in every month. It indicated that ripe eggs of females were ready to release during May to September.

\section{DISCUSSION}

A total number of fish samples obtained in this study is 806 that consists of 425 males and 381 females. The sex ratio of males to females $(1: 0,9)$ was proportional and not significantly different from 1:1. This result was similar to the sex ratio in natural population showing that the number of captured male fish was relatively proportional to the number of female fish (Bal and Rao 


\section{Male}

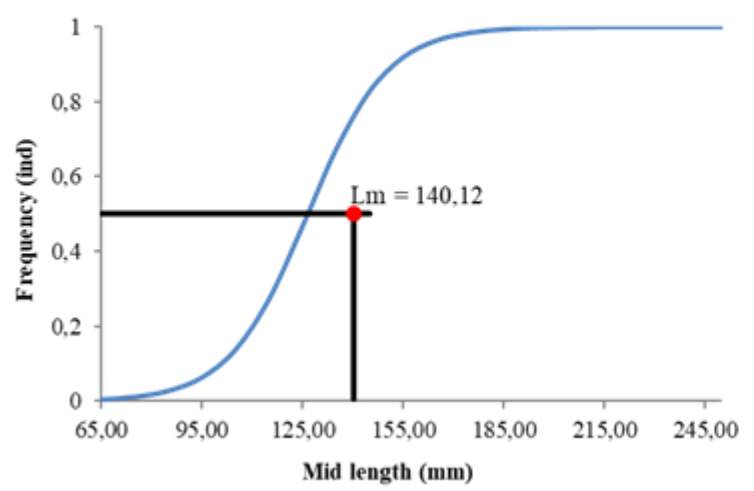

Female

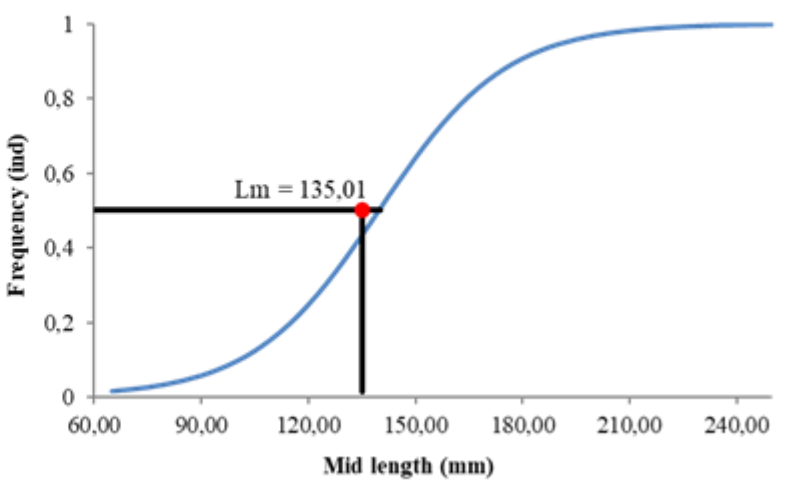

Figure 3 The length at first maturity of Pomadasys argyreus in Palabuhanratu Bay

Male

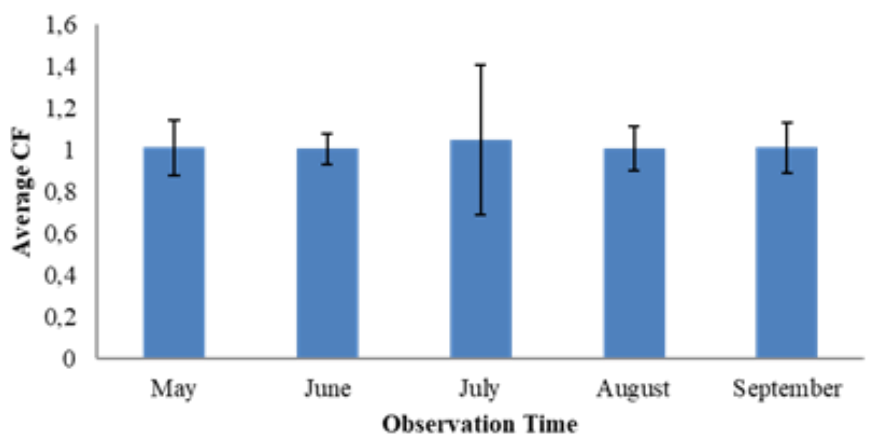

Female

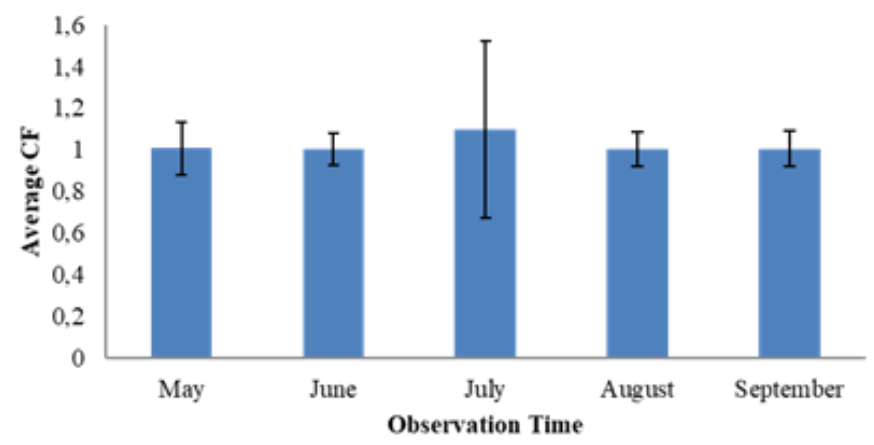

Figure 4 Monthly variations of condition factor for Pomadasys argyreus in Palabuhanratu Bay

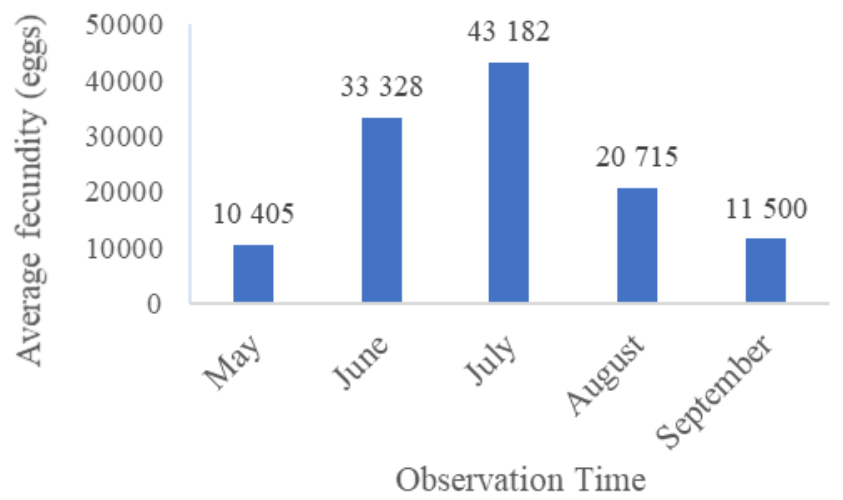

Figure 5 Monthly fecundity of Pomadasys argyreus in Palabuhanratu Bay

The sex ratio in August $(1: 0,66)$ was significantly different. The changes of water temperature, predation, natural risk and migration may be the cause of the differences of sex ratio (Pulungan 2015). Each fish species has variation sex ratio. In generally, the value was near to 1 (Effendie 2002).

$P$. argyreus in Palabuhanratu Bay has a potential to spawn during the sampling time, which is from May to September. The highest frequency of stage IV gonads for males and females $P$. argyreus was found in June. The result indicates that $P$. argyreus spawn throughout the year, with a spawning peak occurred in June. The average total GSI values for male were 1.02, while for female were 1.49 . This result was similar to a state- ment from Biusing (1987) in Sulistiono (2012) that the GSI values of males was lower than females. Growth of female fish is more focused on gonadal growth, which causes the gonad weight of females is larger than males.

The length of first maturity may be used as indicator of availability of reproductive stock (Najamuddin et al. 2004). Males was estimated had their first gonad maturity at length of $\mathrm{L}_{\mathrm{m}}=$ $140,12 \mathrm{~mm}$ and $\mathrm{L}_{\mathrm{m}}=135,01$ for females. This result showed that females reached their first gonad maturity faster than males. Temperature, food, sexes and environmental condition may be the cause of the differences of length at first maturity (Agustina et al. 2015). If the availability of food was high, then the growth rate of fish will in- 

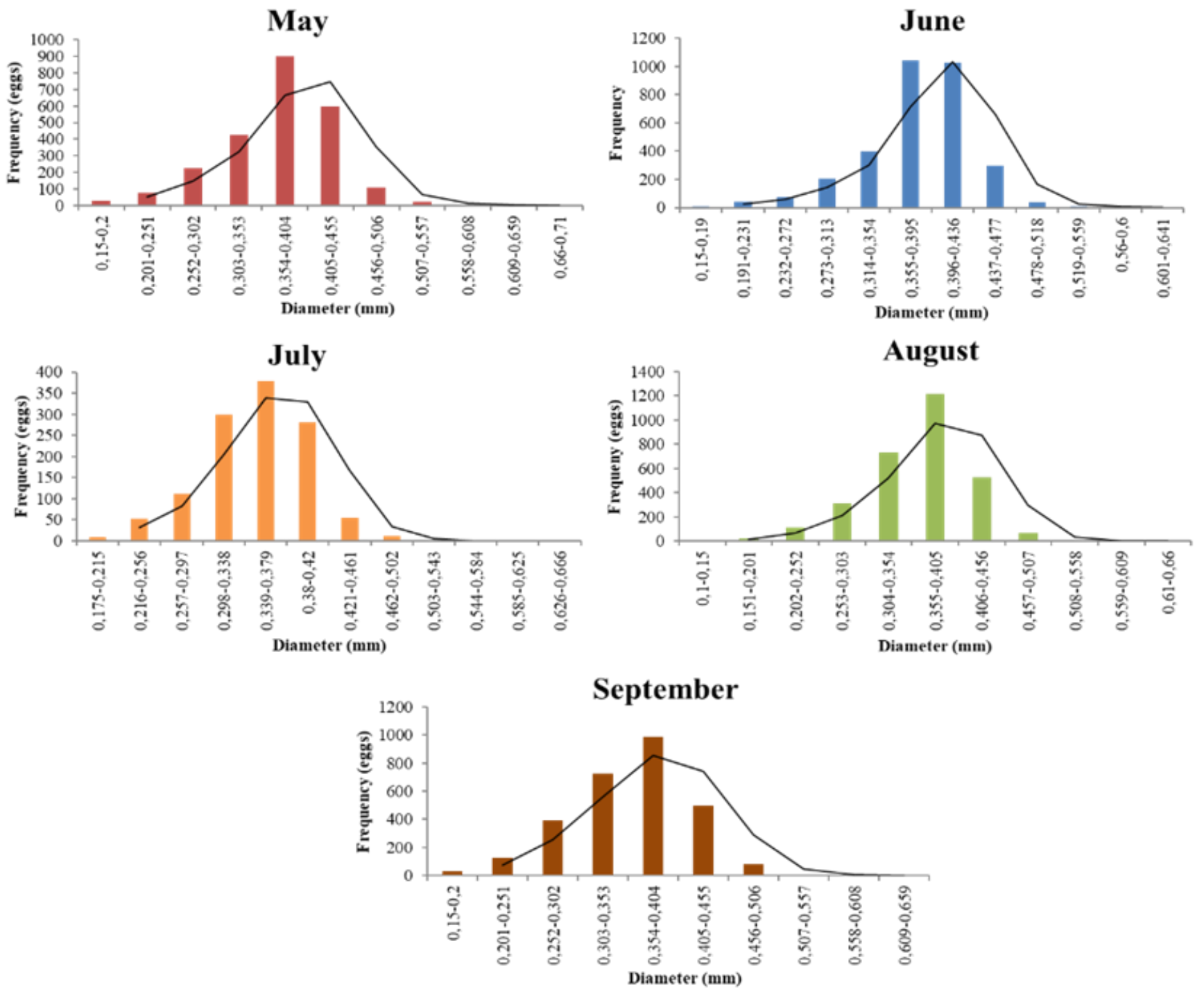

Figure 6 Frequency distribution of diameter of Pomadasys argyreus egg.

crease and fish will reach their first maturity faster (Effendie 2002). The uses of condition factor values commercially have an important meaning in determining the quality and quantity of fish meat (Effendie 2002). High values of condition factor shows there is supporting environment for fish, while low values may be caused by lack of food.

The fecundity of $P$. argyreus in this study was 10.405 to 43.182 eggs for each month, with total average 23.826 eggs. This result is not significantly different to fecundity range of $P$. jubelini was observed by Agbugui (2013) and Adebiyi (2013). Fecundity may be affected by the differences of gonad weight, egg size and environmental conditions. The highest fecundity was found in July. This was related to the result of condition factor that was highest in July, which means fishes in a good condition caused by supporting environment. The diameter of $P$. argyreus's eggs was dominated by size 0,355 to $0,405 \mathrm{~mm}$ in every month, May to September. It indicated that in every month there were ripe eggs in the female fish ready to be release in Palabuhanratu Bay.
Consequently, $P$. argyreus in Palabuhanratu was assumed to be a partial spawner.

\section{CONCLUSSION}

Length at first maturity of Pomadasys argyreus was higher than females. The highest value of condition factor was 1,05 for males and 1,10 for females. This fish spawn partially (partial spawner) and estimated spawns throughout the year with a spawning peak in June.

\section{REFERENCES}

Adebiyi, AM. 2013. The sex ratio, gonadosomatic index, stages of gonadal development and fecundity of Sompat grunt, Pomadasys jubelini (Cuvier, 1830). Pakistan J. Zool. 45 (1):41-46.

Agbugui, MO. 2013. The sex ratio, gonadosomatic index, stages of gonadal development and fecundity of the Grunt, Pomadasys jubelini (Cuvier, 1830) in the New Calabar-Bonny River. Report and Opinion. 5(11). http:// 
www.sciencepub.net/report

Agustina S, Boer M, Fahrudin A. 2015. Population dinamycs of Savalai Hairtail fish (Lepturacanthus savala) in Sunda Strait Waters. Marine Fisheries. 6(1):77-85.

Al-Faisal, AJ and Mutlak FM. 2018. Occurrence of two grunt fish (Haemulidae: Pomadasys) from the Iraqi Marine Waters. International Journal of Marine Science. 8(21):172-175.

Effendie MI. 2002. Biologi Perikanan. Yogyakarta (ID): Yayasan Pustaka Nusatama.

Falahatimarvast A, Poorbagher H, Lokman PM. 2012. The reproductive biology of Pomadasys kaakan (Osteichthyes: Haemulidae) in the northern Persian Gulf. Cahiers de Biologie Marine. 53(1):25-34.

Najamuddin, Achmar M, Budimawan, Indar M. 2004. Estimation the size of the first maturity of round scad (Decapterus macrosoma, Bleeker). Jurnal Sains dan Teknologi. 4(1):18 .

Pulungan CP. 2015. Sex ratio and condition factor of tabingal fish (Puntioplites bulu Blkr) from the Siak River, Riau. Jurnal Perikanan dan Kelautan. 20(1):11-16.

Safi A, Khan MS, Khan MZ. 2014. Study of some morphometric and meristic characters of saddle grunt fish, Pomadasys maculatus (Bloch, 1793), off Karachi Coast, Pakistan. American Journal of Marine Science. 2(2):38 -42 .

Sulistiono. 2012. Reproduction of tank goby (Glossogobius giuris) in Ujung Pangkah Waters, Jawa Timur. Jurnal A kuakultur Indonesia. 11(1):4-75

Tavera JJ, Acero A, Balart EF, and Bernardi G. 2012. Molecular phylogeny of grunts (Teleostei, Haemulidae), with an emphasis on the ecology, evolution, and speciation history of New World species. BMC Evolutionary Biology. 12(57):1-16.

Udupa KS. 1986. Statistical method of estimating the size at first maturity in fishes. Fishbyte. 4 (2):8-10. 